\title{
An epidemiological survey using the Treatment Priority Index (TPI)
}

\author{
Tülin Uǧur, Semra Ciğer, Ata Aksoy and Aslı Telli \\ Department of Orthodontics, Faculty of Dentistry, University of Hacettepe, Ankara, Turkey
}

SUMMARY The purpose of this study was to evaluate the prevalence of malocclusion and to assess the need for orthodontic treatment among 6-10 year old Turkish primary school children. The Treatment Priority Index (TPI) was used to record and measure the malocclusions. The findings were that 40.38 per cent of the observed population showed normal occlusion, 21.85 per cent had minor manifestations of malocclusion and treatment need was slight, 25.17 per cent of the subjects showed definite malocclusion, 7.54 per cent had severe malocclusion and 5.06 per cent had a very severe handicap with a mandatory treatment requirement. Orthodontic treatment need increased between 6 and 10 years of age. No statistically significant difference was found between the mean TPI values of male and female subjects.

\section{Introduction}

Measuring and recording the severity and prevalence of malocclusion is not only important for evaluating the occlusal status of subjects in a community and establishing the treatment priority, but it can be used as an epidemiological tool for preventive procedures or for training orthodontic specialists.

There are several methods that may be used to evaluate, describe and classify occlusion. These can be classified basically as qualitative and quantitative (Tang and Wei, 1993). Qualitative variables define only the presence or absence of a selected malocclusion criteria. A series of malocclusion studies have been undertaken using qualitative methods of assessment (Helm, 1968; Wood, 1971; Baume, 1974; Infante, 1975; Kerosuo, 1990; Kristneli and Shim, 1992). Later, attempts were made to develop an objective method for measuring and recording occlusal features. Two of these quantitative methods were the Occlusal Index (OI; Summers, 1971) and the Treatment Priority Index (TPI; Grainger, 1967). Both the OI and the TPI were similar in many aspects as they were based on the same principle. Although the OI was found to have the least amount of bias (Grewe and Hagan, 1972), its use was too complicated to be applied on large population groups. On the other hand, the TPI had the advantage of being simple and efficient to enable epidemiological surveys of malocclusion possible without undue cost and energy (Slakter et al., 1980).

The purpose of this study was to rank malocclusions and assess the need for orthodontic treatment in relation to age and sex by using the TPI in a group of Turkish primary school children.

\section{Subjects and methods}

Data were collected from 572 students of the Middle East Primary School with a high socioeconomic standard in Ankara. Two-hundredand-fifty-nine girls and 312 boys were examined ranging in age between 6 and 10 years.

Clinical examinations were performed by two experienced orthodontists and the TPI data collection forms were recorded by two others. These four orthodontists were trained and standardized in the use of the TPI. The items measured described the occlusal anomaly such as incisor relationship horizontally and vertically, occlusion of buccal segments and tooth displacement. 


\begin{tabular}{|c|c|c|c|c|c|c|c|c|c|c|c|c|c|c|c|}
\hline \multirow{2}{*}{\multicolumn{4}{|c|}{\begin{tabular}{|c|} 
FIRST \\
MOLAR RELATION \\
Choose appropriate column
\end{tabular}}} & \multicolumn{4}{|c|}{ (6) Distoclusion } & \multirow{2}{*}{$\begin{array}{l}N \\
\vdots \\
u \\
1 \\
0\end{array}$} & \multicolumn{4}{|c|}{ (7) Mesioclusion } & \multirow[b]{2}{*}{ Weights } & \multirow{2}{*}{\multicolumn{2}{|c|}{$\begin{array}{c}\text { Syndrome } \\
\text { Type }\end{array}$}} \\
\hline & & & & $\begin{array}{l}0 \\
\overline{3} \\
\frac{0}{0} \\
\frac{0}{n} \\
\text { N }\end{array}$ & 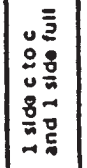 & 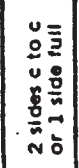 & $\begin{array}{c}u \\
\vdots \\
z \\
\frac{z}{n} \\
\rightarrow\end{array}$ & & \begin{tabular}{l}
0 \\
$\vdots$ \\
$\vdots$ \\
$\vdots$ \\
$\vdots$ \\
\hdashline
\end{tabular} & 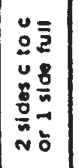 & \begin{tabular}{c|c|}
0 & $\overline{2}$ \\
0 & 8 \\
$u$ & 0 \\
8 & -1 \\
0 & 0 \\
-1 & 5
\end{tabular} & $\frac{0}{\frac{3}{3}}$ & & & \\
\hline \multirow{2}{*}{ 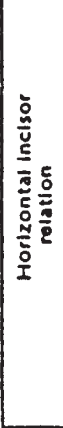 } & (1) Ut & pper Overjet & $\begin{array}{l}\mathrm{mm} \\
9+ \\
9 \\
8 \\
7 \\
6 \\
5 \\
\end{array}$ & $\begin{array}{r}2.0 \\
1.4 \\
1.0 \\
.6 \\
.4 \\
.2 \\
\end{array}$ & $\begin{array}{r}3.4 \\
2.5 \\
1.8 \\
1.1 \\
.6 \\
.3\end{array}$ & \begin{tabular}{|l|}
5.4 \\
4.0 \\
2.8 \\
1.8 \\
1.0 \\
.4 \\
\end{tabular} & $\begin{array}{r}9.3 \\
69 \\
4.8 \\
3.0 \\
1.7 \\
.8 \\
\end{array}$ & $\begin{array}{l}10+ \\
10+ \\
8.0 \\
5.1 \\
2.9 \\
1.3 \\
\end{array}$ & $\begin{array}{r}9.3 \\
6.9 \\
4.8 \\
3.0 \\
1.7 \\
.8 \\
\end{array}$ & $\begin{array}{r}5.4 \\
4.0 \\
2.8 \\
1.8 \\
1.0 \\
.4 \\
\end{array}$ & $\begin{array}{r}3.4 \\
2.5 \\
1.8 \\
1.1 \\
.6 \\
.3 \\
\end{array}$ & $\begin{array}{r}2.0 \\
1.4 \\
1.0 \\
.6 \\
.4 \\
.2 \\
\end{array}$ & & \multicolumn{2}{|c|}{ Retrognathism } \\
\hline & \multicolumn{2}{|c|}{ (2) Lower Overjet } & $\begin{array}{l}1 \\
0 \\
1 \\
2 \\
3 \\
3+\end{array}$ & $\begin{array}{r}.2 \\
.4 \\
.6 \\
1.0 \\
1.4 \\
2.0 \\
\end{array}$ & $\begin{array}{r}.3 \\
.6 \\
1.1 \\
1.8 \\
2.5 \\
3.4\end{array}$ & $\begin{array}{r}.4 \\
1.0 \\
1.8 \\
2.8 \\
4.0 \\
5.4 \\
\end{array}$ & \begin{tabular}{|r|}
.8 \\
1.7 \\
3.0 \\
4.8 \\
6.9 \\
9.3 \\
\end{tabular} & $\begin{array}{l}1.3 \\
2.9 \\
5 . \\
8.0 \\
10+ \\
10+\end{array}$ & $\begin{array}{l}.8 \\
1.7 \\
3.0 \\
4.8 \\
6.9 \\
9.3\end{array}$ & $\begin{array}{l}.4 \\
1.0 \\
1.8 \\
2.8 \\
4.0 \\
5.4\end{array}$ & $\begin{array}{l}.3 \\
.6 \\
1.1 \\
1.8 \\
2.3 \\
3.4\end{array}$ & $\begin{array}{r}.2 \\
.4 \\
.6 \\
1.0 \\
1.4 \\
2.0\end{array}$ & & \multicolumn{2}{|c|}{ Prognathism } \\
\hline \multirow{2}{*}{ 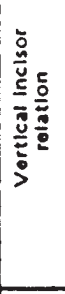 } & \multicolumn{3}{|c|}{$\begin{array}{lc}\text { (3) Overbite in } & \text { Bite } \\
\text { crown } & 3 / 3+ \\
\text { thirds } & 2 / 3-3 / 3 \\
& \\
0.2 / 3 & \end{array}$} & $\begin{array}{r}2.9 \\
1.5 \\
.5\end{array}$ & $\begin{array}{r}3.8 \\
2.0 \\
.7\end{array}$ & $\begin{array}{r}4.8 \\
2.4 \\
.9\end{array}$ & $\begin{array}{l}6.2 \\
3.2 \\
1.1\end{array}$ & $\begin{array}{l}8.0 \\
4.1 \\
1.5\end{array}$ & $\begin{array}{l}6.2 \\
3.2 \\
1.1\end{array}$ & $\begin{array}{r}4.8 \\
2.4 \\
.9\end{array}$ & $\begin{array}{r}3.8 \\
2.0 \\
.7\end{array}$ & $\begin{array}{r}2.9 \\
1.5 \\
.5\end{array}$ & & \multicolumn{2}{|c|}{ Overbite } \\
\hline & \multicolumn{2}{|c|}{$\begin{array}{l}\text { (4) Openbite in } \\
\mathrm{mm} \text {. }\end{array}$} & $\begin{array}{l}<2 \\
2-4 \\
4+\end{array}$ & $\begin{array}{l}1.5 \\
2.9 \\
4.9\end{array}$ & $\begin{array}{l}2.0 \\
3.8 \\
6.3\end{array}$ & $\begin{array}{l}2.4 \\
4.8 \\
7.9\end{array}$ & $\begin{array}{l}3.2 \\
6.2 \\
10+\end{array}$ & \begin{tabular}{l|}
4.1 \\
8.0 \\
$10+$
\end{tabular} & $\begin{array}{l}3.2 \\
6.2 \\
10+\end{array}$ & $\begin{array}{l}2.4 \\
4.8 \\
7.9\end{array}$ & $\begin{array}{l}2.0 \\
3.8 \\
6.3\end{array}$ & $\begin{array}{l}1.5 \\
2.9 \\
4.9\end{array}$ & & \multicolumn{2}{|c|}{ Openbite } \\
\hline 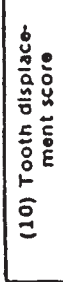 & $\begin{array}{l}\text { Coun } \\
\text { sout } \\
\text { plece } \\
\text { Coun } \\
>45^{\circ} \\
\text { more } \\
\text { Total } \\
\text { score }\end{array}$ & $\begin{array}{l}\text { teoth rotated } \\
\text { t } 45^{\circ} \text { or dis- } \\
\text { d about } 2 \mathrm{~mm} \text {. } \\
\text { it teoth rotated } \\
\text { or displaced } \\
\text { than } 2 \mathrm{~mm} \times 2 \\
10,1 \mathrm{no} \\
10.2 \mathrm{~m}\end{array}$ & $\begin{array}{l}2 \\
3 \\
4 \\
5 \\
6 \\
7 \\
8 \\
9 \\
9+\end{array}$ & \begin{tabular}{|l|}
.1 \\
.2 \\
.3 \\
.5 \\
.7 \\
1.0 \\
1.3 \\
1.7 \\
2.0 \\
\end{tabular} & $\begin{array}{r}.1 \\
.3 \\
.5 \\
.8 \\
1.1 \\
1.5 \\
1.9 \\
2.5 \\
3.0\end{array}$ & $\begin{array}{l}.2 \\
.4 \\
.9 \\
1.2 \\
1.8 \\
2.4 \\
3.1 \\
4.1 \\
4.9 \\
\end{array}$ & $\begin{array}{r}.3 \\
.7 \\
1.2 \\
1.9 \\
2.8 \\
3.9 \\
4.9 \\
6.2 \\
7.7 \\
\end{array}$ & \begin{tabular}{|l|}
.4 \\
1.1 \\
1.9 \\
3.0 \\
4.3 \\
5.9 \\
7.7 \\
9.7 \\
$10+$ \\
\end{tabular} & $\begin{array}{l}.3 \\
.7 \\
1.2 \\
1.9 \\
2.8 \\
3.9 \\
4.9 \\
6.2 \\
7.7 \\
\end{array}$ & \begin{tabular}{|l}
.2 \\
.4 \\
.9 \\
1.2 \\
1.8 \\
2.4 \\
3.1 \\
4.1 \\
4.9 \\
\end{tabular} & $\begin{array}{l}.1 \\
.3 \\
.5 \\
.8 \\
1.1 \\
1.5 \\
1.9 \\
2.5 \\
3.0 \\
\end{array}$ & \begin{tabular}{|l|}
.1 \\
.2 \\
.3 \\
.5 \\
.7 \\
1.0 \\
1.3 \\
1.7 \\
2.0 \\
\end{tabular} & & $\begin{array}{l}\text { Is distoc } \\
\text { and/or p } \\
\text { crossblt } \\
\text { to buc } \\
\text { PRES } \\
\text { Y's } \\
\text { Max. } \\
\text { Expanslon } \\
\text { Syndrome }\end{array}$ & $\begin{array}{l}\text { lusion } \\
\text { osterior } \\
\text { e max. } \\
\text { cal } \\
\text { ENT } \\
\text { Max. } \\
\text { Collapse } \\
\text { Syndrome }\end{array}$ \\
\hline \multicolumn{4}{|c|}{ CONSTANT } & 5.17 & 3.95 & 2.72 & 1.50 & 0.27 & 1.50 & 2.72 & 3.95 & 5.17 & & & \\
\hline \multirow{4}{*}{\multicolumn{2}{|c|}{ 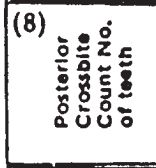 }} & $\begin{array}{l}\text { MAX. TO } \\
\text { BUCCAL }\end{array}$ & No. & 0 & \begin{tabular}{l|l|}
1 & 2 \\
\end{tabular} & 3 & 4 & 5 & 6 & 7 & 8 & more & & & \\
\hline & & DUCLL & Wolght & 01. & \begin{tabular}{|l|l|}
.1 & .6 \\
\end{tabular} & 1.3 & 2.2 & 3.5 & 5.0 & 6.9 & 9.0 & 10 & & & \\
\hline & & $\begin{array}{l}\text { MAX. TO } \\
\text { LINGUAL }\end{array}$ & No. & 01 & $1|2|$ & 3 & 4 & 5 & \multicolumn{3}{|c|}{6 more } & & & & \\
\hline & & & Welght & 0. & \begin{tabular}{l|l|}
.3 & 1.0 \\
\end{tabular} & 2.3 & 4.2 & 6.5 & 9.4 & 10 & & & & & \\
\hline
\end{tabular}

Figure 1 The TPI data collection form.

These syndromes were weighted according to the first molar relationship as mesio, neutro and distoclusion (Figure 1). The weights that corresponded to the recorded syndromes were summed and a total TPI score was calculated for each subject. The level of severity of a malocclusion was assessed according to the Malocclusion Severity Estimate (MSE) (Grainger, 1967). A modification of this scale was used in the present study (Ghafari et al., 1989) with the exception that the constant value for neutroclusion on the TPI form was scored for normal occlusion. In this 
Table 1 Levels of severity of a malocclusion as established by the malocclusion severity estimate (MSE) and for the present study.

Interpretation

MSE

Study

I. Virtually classic normal occlusion

II. Minor manifestations of malocclusion and treatment need is slight

0

1-3

4-6

$7-9$

$>10$ $\leq 0.27$

$0.27-\leq 3.99$

$3.99-\leq 6.99$

$6.99-\leq 9.99$

V. Very severe handicap with treatment mandatory

regard, the severity level for normal occlusion was assessed as 0.27 and for minor manifestations of malocclusion as $0.27-\leq 3.99$ (Table 1). Subjects who had previous orthodontic treatment were excluded from the evaluation.

\section{Statistical analysis}

The TPI differences between 6-10 years were examined using the Kruskal-Wallis one-way analysis of variance. Age groups were then compared two by two using the Mann-Whitney $U$-test. Sex difference was also evaluated using the MannWhitney $U$-test.

\section{Results}

A normal occlusion was present in 40.38 per cent of the population, 21.85 per cent had a slight malocclusion, 25.17 per cent had a definite malocclusion, 7.52 per cent had a severe malocclusion and 5.08 per cent had a very severe malocclusion (Table 2, Figure 2).

The mean TPI values showed a significant increase between 6-8, 6-9, 6-10, and 7-8, 7-9, $7-10$ years of age $(P<0.05)$ (Table 3$)$.

Table 2 Percentage of the subjects according to malocclusion severity.

\begin{tabular}{lll}
\hline Subjects (\%) & Malocclusion & Treatment need \\
\hline & & \\
40.38 & Normal occlusion & - \\
21.85 & Minor & Slight \\
25.17 & Definite & Elective \\
7.52 & Severe & Highly desirable \\
5.08 & Very severe & Mandatory \\
\hline
\end{tabular}

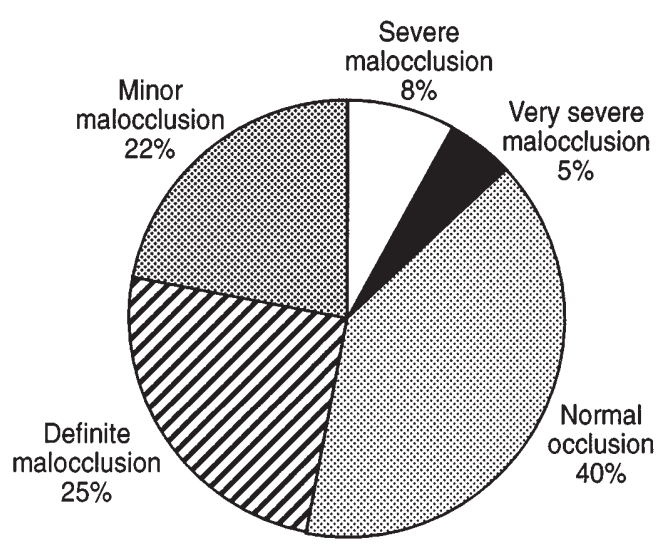

Figure 2 The distribution of malocclusion severity.

The difference between the mean TPI values of boys and girls was not found to be significant (Table 4).

\section{Discussion}

The purpose of this study was to measure the prevalence and severity of malocclusions in 6-10-year-old Turkish primary school children. The TPI was selected for this evaluation as it has

Table 3 The TPI statistics between ages 6-10.

\begin{tabular}{llllll}
\hline Age & $n$ & Mean & Min & Max & SD \\
\hline 6 & 120 & 2.31 & 0.27 & 16.77 & 2.99 \\
7 & 129 & 3.02 & 0.27 & 15.37 & 3.71 \\
8 & 117 & 3.24 & 0.27 & 12.17 & 3.17 \\
9 & 117 & 4.14 & 0.27 & 19.17 & 3.75 \\
10 & 89 & 3.31 & 0.27 & 11.57 & 3.08 \\
\hline
\end{tabular}


Table 4 The TPI statistics of boys and girls.

\begin{tabular}{lllllll}
\hline & $n$ & Mean & Min & Max & SD & $P$ \\
\hline Boys & 312 & 3.34 & 0.27 & 16.77 & 3.31 & \\
Girls & 259 & 3.08 & 0.27 & 19.17 & 3.50 & \\
\hline
\end{tabular}

proved to be a useful epidemiological indicator of malocclusion (Ghafari et al., 1989). Some disadvantages were noted about the TPI such as deleting the mixed dentition analysis when the original MSE was revised, and giving the same score for distal and mesial molar relationships. On the other hand, there is no universally accepted index that defines all characteristics of a malocclusion as this is a multifactorial problem (Tang and Wei, 1993). In addition, the advantages of this index are much more important. It has been found to be highly reproducible and valid (Hermanson and Grewe, 1970; Albino et al., 1978). Application of the TPI is practicable and requires less clerical time when compared with the OI (Tang and Wei, 1993). Thus, the TPI is a useful index for measuring need for treatment and as an aid in the identification of children who can most benefit from orthodontic treatment (Slakter et al., 1980).

In this study, 572 children with a high socioeconomic standard were evaluated and 40.38 per cent showed normal occlusion, 21.85 per cent had minor manifestations of malocclusion, 25.17 per cent had a definite malocclusion, 7.52 per cent had a severe, and 5.08 per cent had very severe malocclusions. By using the TPI, Güray et al. (1994) found 72.26 per cent of 483 students required orthodontic treatment in a primary school with a low socio-economic standard from Konya district. Güray et al. (1994) used the modified MSE (Ghafari et al., 1989).

Orthodontic treatment need increased with age in the present study. Güray et al. (1994) found no age differences, whereas Ghafari et al. (1989) reported a decrease in TPI values with increasing age and explained this as the inability of the TPI to depict crowding of the unerupted permanent canines and premolars.
The mean TPI values of male and female subjects showed no statistically significant difference and this is in agreement with Güray et al. (1994). However, Ghafari et al. (1989) found that crowding and rotation were more severe in males than female subjects, and made the assumption that growth proceeding over a longer period of time contributed to the development of greater displacement in boys.

This study was undertaken in a primary school with a high socio-economic standard. However, similar TPI scores were recorded from an area with a low socio-economic standard (Güray et al., 1994). These results underscore the high percentage of orthodontic treatment need in Turkey and indicate the importance of preventive orthodontic procedures.

\section{Address for correspondence}

Dr Tülin Uğur

Department of Orthodontics

Faculty of Dentistry

University of Hacettepe

06100 Ankara

Turkey

\section{Acknowledgement}

We would like to express our thanks Dr P. Emile Rossouw, Department of Orthodontics, University of Toronto, for supplying details of the Treatment Priority Index.

\section{References}

Albino J E, Lewis E A, Slakter M J 1978 Examiner reliability for two methods of assessing malocclusion. Angle Orthodontist 48: 297-302

Baume L J 1974 Uniform methods for the epidemiologic assessment of malocclusion. American Journal of Orthodontics 66: 251-272

Ghafari J, Locke S A, Bentley J M 1989 Longitudinal evaluation of the Treatment Priority Index (TPI). American Journal of Orthodontics and Dentofacial Orthopedics 96: 382-389

Grainger R M 1967 The orthodontic treatment priority index. Public Health Service Publication no. 1000 (Vital and Health Statistics) Series 2, No. 25. Washington DC: National Center for Health Statistics 
Grewe J M, Hagan D V 1972 Malocclusion indices: a comparative evaluation. American Journal of Orthodontics 61: 286-294

Güray E, Orhan M, Ertaş E, Doruk C 1994 Konya Yöresi Ilkokul Çocuklarında Treatment Priority Index (TPI) Uygulaması (Epidemiyolojik Çalişma). Türk Ortodonti Dergisi 7: 195-200

Helm S 1968 Malocclusion in Danish children with adolescent dentition: an epidemiologic study. American Journal of Orthodontics 54: 352-366

Hermanson P C, Grewe J M 1970 Examiner variability of several malocclusion indices. Angle Orthodontist 40: 219-235

Infante P F 1975 Malocclusion in the deciduous dentition in White, Black and Apache Indian children. Angle Orthodontist 45: 213-218

Kerosuo H 1990 Occlusion in primary and early mixed dentitions in a group of Tanzanian and Finnish children. Journal of Dentistry for Children 85: 824-833
Kristneli M, Shim Y S 1992 Malocclusion, body posture, and temporomandibular disorder in children with primary and mixed dentition. Journal of Clinical Pediatric Dentistry 16: 86-93

Slakter M J, Albino J E, Green L J, Lewis E A 1980 Validity of an orthodontic treatment priority index to measure need for treatment. American Journal of Orthodontics 78: $421-425$

Summers C J 1971 The occlusal index: a system for identifying and scoring occlusal disorders. American Journal of Orthodontics 59: 552-567

Tang E L K, Wei S H Y 1993 Recording and measuring malocclusion: A review of the literature. American Journal of Orthodontics and Dentofacial Orthopedics 103: $344-351$

Wood B F 1971 Malocclusion in the modern Alaskan Eskimo. American Journal of Orthodontics 60: 344-354 